\title{
Dansk møde- og foreningsliv i Tønder på sprogreskripternes tid
}

\author{
Af Asger Nyholm.
}

Hvad man i vor tid forstår ved dansk møde- og foreningsliv, har der ikke været i Tønder før 1850. Derimod finder man et halvt århundrede tidligere omtalt „Die Schleswig-Holsteinische patriotische Gesellschaft". - Det var en forening, der var stiftet 29. september 1812 i Altona. Den havde til formål inden for de to hertugdømmer at virke til gavn for samfundet $i$ ubrydelig hengivenhed for konge og fædreland. Den var - som Borgerdydselskabet og som Selskabet for Efterslægten i København - stiftet som et udslag af oplysningstidens reformivrige og samfundsinteresserede borgerånd. Den var tillige udtryk for den patriotisme, der fandtes i de tysktalende dele af den danske helstat, der strakte sig helt til Elben.

I Tønder har der været en afdeling af denne forening. I 1822 oplyses det, ${ }^{1}$ at seminariets daværende forstander, Jacob Decker, var foreningens forretningsfører for Abild, Christian-Albrechtskog, Dedsbøl, Løgumkloster og Tønder, og det hedder, at selskabet er loyalt overfor „den so innig verehrten König“.

Et par oplysninger belyser yderligere kongetroskaben i Tønder ved denne tid. I forhandlingsprotokollen for direktionen for Tønder Seminarium² hedder det, at den 25 . jan. 1814 besluttede direktionen „den Geburtstag des Königs zum 1sten Male im hiesigen Seminar zu feiern“. Og videre oplyses for den 14 . januar 1816 , $^{3}$ at direktionen besluttede, „dass der Geburtstag des Königs gewöhnlichermassen gefeiert werden sollte“. I 1817 beretter „Provinzialberichte ${ }^{\text {" } 4}$ om kongefesten: i fire år har seminariets direktion fejret kongens fodselsdag $i$ erindring om sin pligt til at benytte enhver lejlighed til at vække kærlighed til konge og fædreland hos eleverne... og $i$ erindring om den særlige opmærksom- 


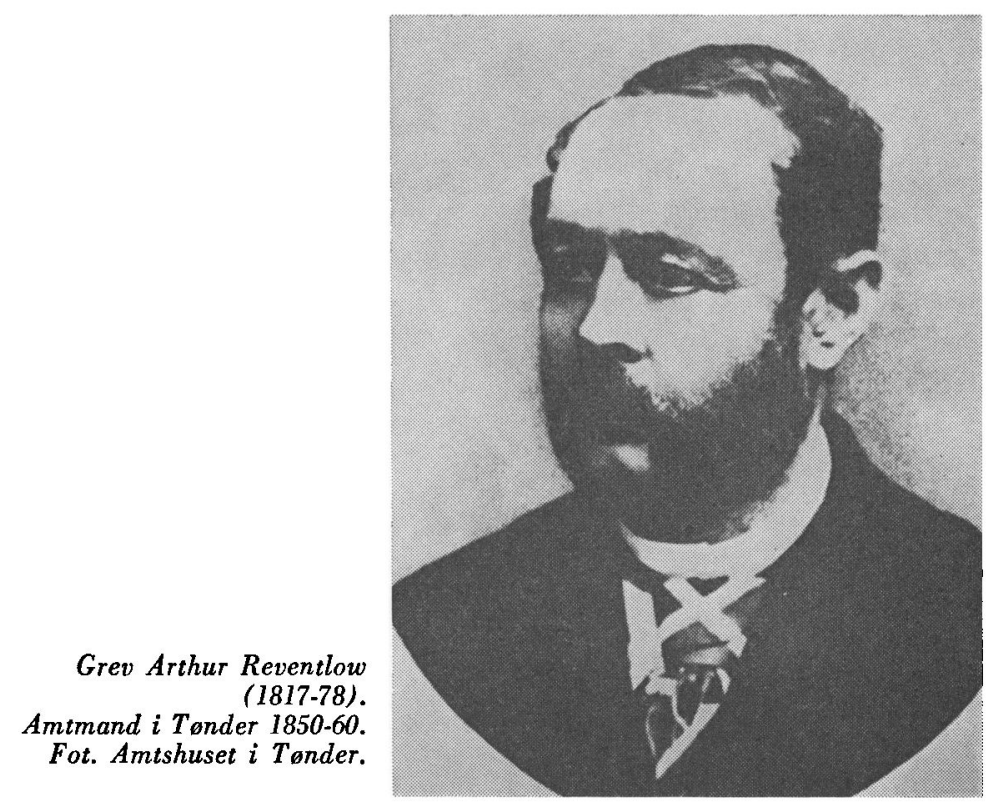

hed og bevågenhed, som denne anstalt møder fra kongens side. En del af byens indbyggere var indbudt. Cantor Valentin Juhl havde hvert år affattet en kantate, og forstander Decker holdt talen. "Nie ging die Versammlung ungerührt und ohne die heissesten Wünsche für König und Vaterland auseinander".

Disse spredte notitser er vidnesbyrd om den gamle tids helstatsmentalitet. Både danske og holstenere var den danske konges undersåtter, og deres patriotisme, som det dengang hed, ytrede sig først og fremmest i kongetroskab. Den kunde lige så vel ytre sig på dansk som på tysk, og de omtalte kongefester og det patriotiske selskabs møder er givetvis foregået på tysk.

Den form for patriotisme, der trivedes inden for den gamle helstat, fik sit grundskud med den slesvig-holstenske bevægelse. Denne havde sine sympatier mod syd, i tysk kultur og tysk sprog, og den stilede mod en fortyskning af Slesvig. Heroverfor rejste der sig naturligt en modstand fra de kredse, som vilde bevare dansk kultur og dansk sprog i Slesvig. Som et led i kampen mod Slesvig-Holstenismen stiftedes i 1843 Slesvigsk Forening. 
Denne forening havde særlig tilslutning i Haderslev-egnen. Efter foreningsprotokollen ${ }^{5}$ at dømme fik den ingen medlemmer i Tonder i 1840'erne. Der var heller ikke jordbund for en sådan forening $\mathrm{i}$ byen. Tønders ugeavis, "Tondersche Intelligenzblatt“, var fra 1840 skarpt antidansk. Byens repræsentant på stænderforsamlingen var fra 1841 den aggressive slesvig-holstener Wilh. Beseler. Der blev i byen oprettet en "Singverein“, hvis fane bar de slesvig-holstenske farver.

Efter krigen 1848-50 ændredes imidlertid billedet.

I 1851 udstedtes de såkaldte sprogreskripter. Deres ophavsmand var Th. A. J. Regenburg, der i 1850 havde fået overdraget bestyrelsen af de sønderjyske kirke- og skolesager. Efter disse reskripter skulde der i henved et halvt hundrede sogne i Mellemslesvig (Tønder indbefattet) indføres dansk skolesprog og skiftevis dansk og tysk gudstjeneste - dog således, at man frit kunde vælge sproget ved dåb, bryllup og begravelse.

I disse egne havde kirke- og skolesprog hidtil været tysk, skønt befolkningens daglige sprog mange steder, bl. a. i Tønder, overvejende var dansk.

En række danske embedsmænd blev ansat i disse områder for at gennemføre den sproglige nyordning. Også Tønder fik en stab af danske embedsmænd. De arbejdede med ungdommelig begejstring. En af dem skrev mange år senere: ${ }^{6}$ „Der var Liv og Fart i det danske Arbejde i de første Aar, da Sejrsfølelsen bar højt og Arbejdsmarken laa saa vinkende i Haabets skønne Lysspil“. Man var enige om, at „den tyske Gøgeunge skulde smides ud af Reden og rømme Marken“.

Man skulde tro, at der med denne kreds af danske embedsmænd, der i fællesskab skulde arbejde for "den gode Sag“, som man kaldte sprogsagen, var skabt basis for dansk foreningsliv i byen. Der er herom ikke oplyst meget. I det følgende skal de sparsomme vidnesbyrd om dansk møde- og foreningsliv $i$ denne periode fremdrages. -

I begyndelsen synes der virkelig at have været noget $i$ retning af en dansk forening. Borgmester Kjær skriver den 12. maj 1851 $i$ et brev til Regenburg, ${ }^{7}$ at en dansk forening $i$ Tønder er $i$ fødselen.

Den 22. april $1853^{8}$ fortæller Kjær i brev til Regenburg, at 
Chr. Albert Kiar (1825-77).

Konst. borgmester $i$ Tonder 1851-53. Fot. Folketingets arkiv.

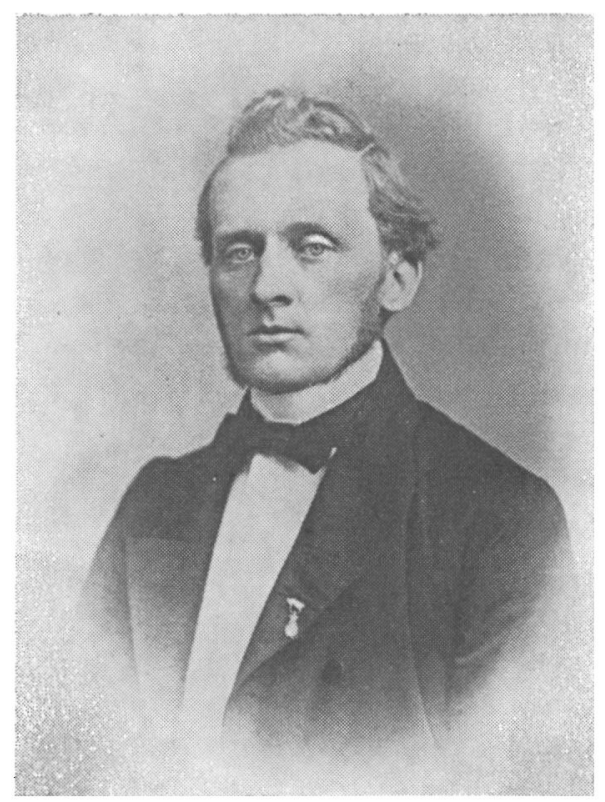

blandt medlemmerne i „den danske Club“ er magistraten, Dahl og rektoren. Magistraten, dvs. Kjær selv og dernæst de to dansksindede rådmænd, farver A. T. Diemer og bogbinder E. Jacobsen. Chr. Alb. Kjær var en embedsmandssøn fra København og havde - som så mange af de nye embedsmænd i landsdelen - under sin skolegang i Sorø modtaget en kraftig national påvirkning af sin historielærer, C. F. Wegener. 26 år gammel blev han borgmester i Tønder. I $1853 \mathrm{blev}$ han herredsfoged for Tønder og Højer herreder. Med stor energi havde han taget fat på gennemførelsen af sprogskiftet $\mathrm{i}$ byens skoler. „Hvad der skete i dansk Retning til Skolens Tarv, skete ved ham", hed det. De to rådmænd var blevet udnævnt af kongen i 1851, da de tidligere fire magistratsmedlemmer trak sig tilbage som protest mod den nye sprogordning. De viste, som Kjær senere skrev, ${ }^{9}$ „Mod og Fædrelandskjærlighed nok til at overtage et Hverv, der paadrog dem Flertallets Had og Spot og et vist Næringstab“. Johs. Matth. Dahl var byens andenpræst. Han havde til opgave at holde de danske gudstjenester og tillige som inspektør for byens skoler at sørge for, at der 
blev indført dansk undervisningssprog $\mathrm{i}$ alle skolerne, der hidtil havde været tysksprogede. Endelig nævnes „rektoren“, dvs. lederen af den såkaldte rektorklasse, præstesønnen fra Gram, Niels Wiborg Müller, der i 1856 blev realskolebestyrer i Thisted og siden inspektør for realskolerne i Danmark.

Imidlertid spores allerede på dette tidspunkt en spaltning inden for kredsen af danske embedsmænd. Amtmanden, grev Arthur Reventlow, så ikke med velvilje på den danske forening. Han stammede fra Sandbjerg, var tysk opdraget, men havde kæmpet på dansk side $\mathrm{i}$ treårskrigen. Han havde $\mathrm{i}$ sin betænkning til forslaget til sprogreskripterne hævdet, at oppositionen mod reskripterne ikke var berettiget. Men han mente, man burde tage denne opposition i betragtning og undgå at give den ny næring. For Tønder bys vedkommende havde han anbefalet at lade byens kollegier (dvs. magistraten og deputeretkollegiet) udtale sig, inden man traf beslutning om sprogordningen. Det kan være vanskeligt at danne sig et klart billede af grev Reventlow. Mange ubeherskede angreb på ham kan let komme til at forvanske billedet. Det er muligt, at en vis usmidighed har skadet hans position. Han synes at have været indstillet på den helstatskurs, som den danske regering under pres fra udlandet så sig nødsaget til at følge, og havde formodentlig også i sig den gamle helstatstankegang, for hvilken modsætningsforholdet mellem dansk og tysk føltes som noget unaturligt. Han onskede at holde igen overfor alt for aggressive danske tendenser og blev til gengæld betragtet med stor mistænksomhed af mange af de dansksindede. Kjær fortæller i samme brev til Regenburg i april 1853, at grev Reventlow havde advaret en af byens nyansatte lærere, Vilh. Hagerup, mod at „besøge den danske Club".

Et socialt skel synes at have gjort sig gældende i de danskes kreds. I november 1852 læser man $i$ "Dannevirke“"10, at kongens fødselsdag (6. okt.) var blevet fejret ved et middagsgilde på rådstuen og et aftensbord og bal hele natten $i$ seminariebygningen. Bladet fortsætter: „Saa meget synes os klart, at hellere end Embedsmændene skulde forsøge, paa en saadan Dag, at gjøre Borgerne og Menigmand fornemme, skulde de stige ned til disse og more sig med dem i al borgerlig Jævnhed.“

Først i 1856 høres der atter om „Danske Samfund“. „Danne- 


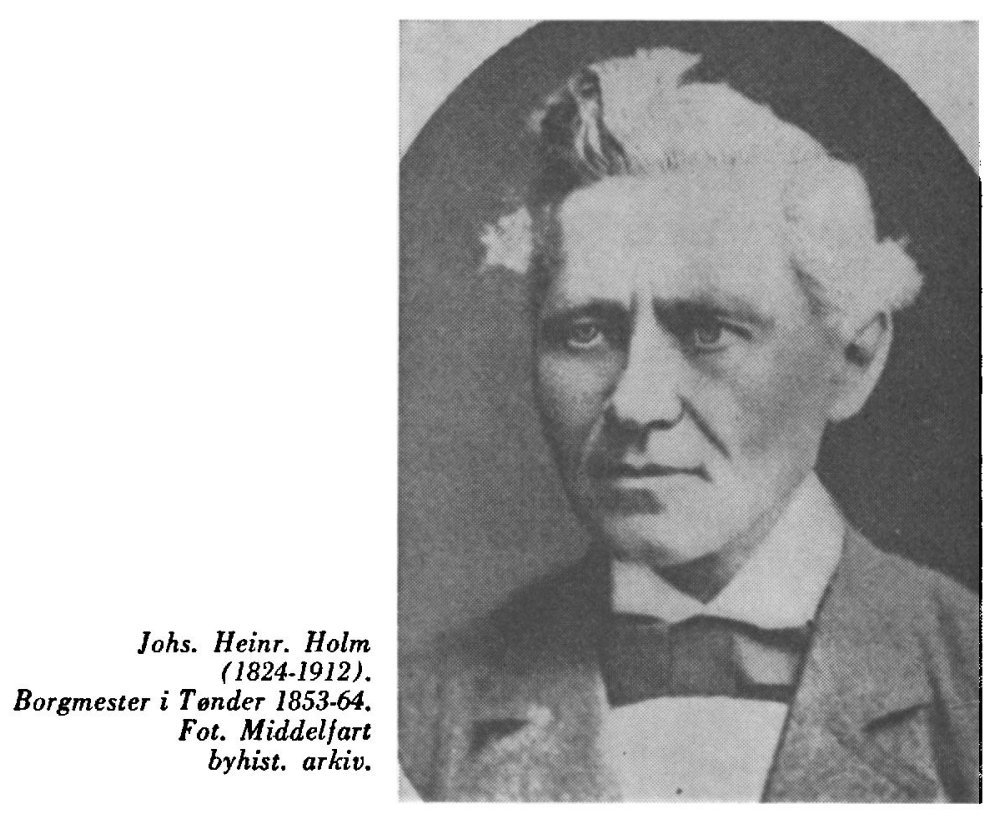

virke beretter, ${ }^{11}$ at ved mødet den 13 . januar var der "vel nogle færre Gjæster samlede end sidst, men Sammenkomsten manglede dog hverken Liv eller Munterhed. Flere gode Foredrag holdtes, blandt hvilke nævnes en Udsigt over Fædrelandshistorien, med særligt Hensyn til Sønderjylland, af Skolelærer Tranberg i Tønder, ligesom Thingskriver Refslund sammesteds fortalte forskjellige Minder fra vore Egne, der for en stor Deel er Flerheden ubekjendte, og nu kun leve i Folkemunde. Ligeledes talte Borgermester Holm, Pastor Koch, Ley fra Forballum o. fl. med Kraft og Begeistring, og flere Fædrelandssange bleve afsunget".

Det er værd at mærke sig navnene på disse talere. Det siger noget om mentaliteten i denne kreds. Den nævnte skolelærer P. Tranberg, der var lærer $i$ Tønder 1853-56 og senere kom til at spille en vis rolle i kredsen omkring Vallekilde højskole, var, som flertallet af byens nye danske skolelærere, grundtvigsk indstillet. Tingskriver Refslund var gift med en datter af Knud L. Knudsen i Forballum, havde altså tilknytning til den grundtvigske kreds i Vestslesvig, som kan føres tilbage til præsterne Hass og 
Hagen i Mjolden, og indenfor hvilken Kristen Kold havde haft sit virke. Til denne kreds hørte også Chr. Siegfr. Ley, Grundtvigs begejstrede discipel, der var huslærer på vesteregnen. (Det bør med det samme tilføjes, at mødet efter al sandsynlighed er blevet holdt i "Humlekærren“, den gamle bygning med den smukke gavl, der endnu ligger umiddelbart vest for rådhuset. Det var en gammel gastgivergård, hvor i en fjern fortid særlig humlesælgerne havde holdt til. Knud L. Knudsen havde overtaget den efter en tvangsauktion, havde i 1846 forpagtet den til Hans Hansen Hage og hans hustru, Mette Marie Hage, der havde tjent hos Knudsen, og disse havde i 1851 overtaget kroen)..$^{12}$ Blandt de ovrige talere nævnes Kjærs efterfølger som borgmester, den mere afbalancerede Johannes Holm, søn af birkefogeden i Møgeltønder. Holm var som tyveårig student $\mathrm{i}$ København blevet medlem af Slesvigsk Forening. ${ }^{13}$ Endelig nævnes pastor Koch i Burkal, der var stærkt påvirket af Søren Kierkegaard, selv om denne i „sine sidste „Øieblikke" har sagt Adskilligt, som ingen Christen kan være enig $i^{\prime \prime} .{ }^{14}$

De navne, der her er nævnet, særlig de, der har tilknytning til grundtvigske kredse, tyder på, at de senere såkaldte „Klosterbrødre“ var ved at sætte deres præg på „Danske Samfund“. Det bekræftes, når man læser beretningen om kongens fødselsdag samme år. "Dannevirke"15 ved at fortælle, at dagen blev fejret af embedsmændene ved en middag på rådstuen, hvor herredsfoged Cohen i sin tale udtalte det ønske, at borger og bonde $i$ fremtiden måtte tage del $i$ højtideligholdelsen af dagen. Man har altså hos embedsmændene været klar over, at der var et socialt skel, der burde overvindes. Men at også et andet skel gjorde sig gældende, kan man se af referatets fortsættelse: „I „Danske Samfund * talte Ley om middelalderens kæmpeviser, Appel talte for hengivenheden mellem konge og folk, Ley talte for Nordens Enhed, dvs. en åndelig enhed, der måtte være mulig også uden fælles kongehus. Dahl fremhævede, at danskhed ikke er noget udvortes, men kun den er virkelig dansk, hvem denne Sag var bleven en Hjertesag“.

„Danske Samfund“ holdt altså møde for sig selv. Der blev talt om folkeminder, og der blev talt om fædrelandsfølelse og skandinavisk fællesfølelse som noget, der skulde være et hjerteanliggen- 


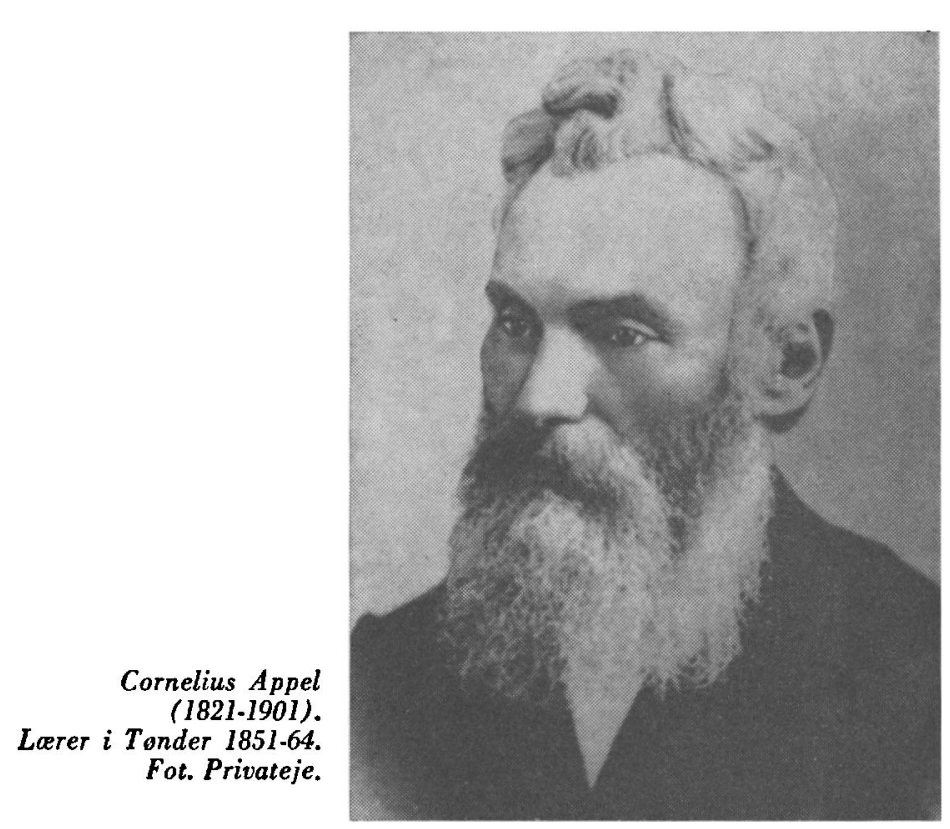

de. Her er det nye navn: Cornelius Appel, Rødding højskoles forstander efter 1864. Han var i 1851 blevet lærer $i$ Tønder. Han og Dahl blev nære venner. Begge var stærkt optaget af Søren Kierkegaards skrifter og følte stærkt brodden i de beskyldninger for åndelig uredelighed, som Kierkegaard rettede mod livet $\mathrm{i}$ den danske kirke. Men med sin grundtvigske indstilling fandt Appel - og Dahl fulgte ham deri - en vej ud af miseren i en kirkelig lovgivning, der gjorde det muligt for mennesker at stå frit i brugen af kirkelige handlinger, hvad de ikke gjorde i Slesvig, hvor junigrundloven og dens bestemmelse om religionsfrihed ikke var gældende. Heri var de ganske på linie med Ley, der særlig havde rettet sin opmærksomhed på konfirmationen. Allerede i 1851 havde han sagt om konfirmationen, ${ }^{16}$ at den "lokker unge Mennesker aarlig $\mathbf{i}$ Tusindviis til at træde ind $\mathbf{i}$ det borgerlige Samfund med en Løgn under Helligheds Kaabe paa Læberne".

Impulsiv som han var, havde Dahl $i$ foråret 1855 i en prædiken talt om „de uchristelige og ubarmhjertige Love, som følges i Kirke og Skole“. Han havde dermed sigtet til den kirkelige lov- 
givning, som den tog sig ud, set med grundtvigske øjne — måske sigtede han forst og fremmest til konfirmationen. Men da myndighederne troede, at det drejede sig om et angreb på sprogreskripterne, som han jo tilmed var ansat for at gennemføre, blev sagen ret alvorlig for Dahl, der mátte afgive et skriftligt løfte om at vise lovene skyldig agtelse og lydighed. Dahl var altså under skarp observation fra sine foresatte, amtmanden og byens førstepræst, provst Tidemand.

Men dertil var yderligere kommet det, at trekløveret DahlAppel-Ley var gâet $i$ aktion for at få gennemført en ændret praksis med hensyn til konfirmationen.

Denne bestod $\mathrm{i}$ to handlinger: overhøringen og den egentlige kirkelige handling, aflæggelsen af konfirmationsloftet. Provst Tidemand havde under megen modstand fâet sat igennem, at begge handlinger skulde gennemfores på dansk, idet de begge under eet blev betragtet som afslutning på skolegangen og derfor skulde foregå på skolens sprog. Nu rejste den grundtvigske fløj i den religiøse ærligheds navn krav om, at den kirkelige del af handlingen skulde være frivillig. Men heraf vilde nødvendigvis følge, at denne del af konfirmationen vilde falde ind under de samme regler i sprogreskriptet, som gjaldt for barnedåb, bryllup og begravelse, hvorefter sproget vilde blive valgfrit. Det måtte betragtes som et nederlag for den danske sprogpolitik. Det måtte Tidemand protestere imod - ja, der var dem, der mente, at den bevægelse, der her var ved at opstå, var næsten værre end oprøret i 1848.

Og det grundtvigske trekløver gik som sagt til aktion. De holdt møder for at vinde tilslutning for deres tanker. Tør man tro Tidemand, søgte de endda at vinde tilslutning for deres kirkelige frihedstanker hos de nationale modstandere. Tidemand skriver 19. marts $1856^{17}$ dybt rystet til Regenburg: „Han (Dahl) og Skolelærer Appel har indbudt i næstforrige Uge til et kirkeligt Møde paa en Gjæstgivergaard [sikkert „Humlekærren“] her i Byen, og ikke blot ladet sig nøie med at indbyde adskillige danske Præster, men har indbudt - Slesvigholsteneren Carstens [byens trediepræst, der havde de tyske gudstjenester], som troede det var min Spøg, at ville have dansk Confirmation i Tønder, og 3 enragerede Slesvigholstenere, deriblandt 2 deputerede Borgere for at raad- 
slaae om kirkelige Forhold i fri Retning. Saavidt er det nu kommen, at disse ikke undsee sig ved at slutte eller forsøge paa at slutte sig til Slesvigholstenerne for at sætte deres kirkelige Anskuelse igennem ... Skal det blive ved i den Retning, ville disse Folk jo nødsages til at fordre Sprogrescriptet hævet, thi det bliver da en af de første Consequentser..."

Trekløveret, suppleret med N. V. Müller, holdt også - tilsyneladende uden større resultat - nogle møder i Vesterkroen i Møgeltønder, hvor de søgte at vinde tilhængere, medens Tidemand forbitret klagede til Regenburg ${ }^{18}$ over disse moder, der kunde „bære Spiren til Tilintetgjørelsen af vor Gjerning i Henseende til Sproget“.

På denne baggrund forstår man, at embedsmændene ved deres middag på rådstuen lagde luft mellem sig og „Danske Samfund“. Men man forstår også, at de har næret et levende ønske om, „at Borger og Bonde i Fremtiden maae tage Deel i Højtideligholdelsen af Dagen“. Så vidste man da, at de $i$ hvert fald så længe ikke lyttede til rebellerne i „Danske Samfund“.

Den splittelse, der var $\mathrm{i}$ danske kredse, lykkedes det ikke det danske seminarium at bøde på.

Hidtil havde seminariet været tysksproget. Men det blev i 1855 med sin - i ovrigt helstatsvenlige og kongetro - forstander, professor Bahnsen, flyttet til Eckernførde. Den 7. januar 1858 genåbnedes seminariet som dansksproget af den nye forstander, professor Arnold Kühnel, der i sin åbningstale erklærede: „Fra denne Læreranstalt bør ingen udgaa, som ikke kan udgaa med et dansk Sind og et dansk Hjerte, med Kærlighed til Kongen, Fædrelandet og Fædrenes danske Sprog“.

Kühnels kurs var således klar, og hans elever synes at have fulgt den. Han sørgede selv for, at de kun blev indkvarterede hos dansktalende familier, og han krævede af elevernes værtsfolk, at de flagede med Dannebrog på kongens fødselsdag. Efter stændervalget 1860 gav han de elever ordre til at opsige deres logi, hvis værter havde stemt på tyske kandidater. Hans nationale modstandere kaldte ham professor "Wurzelreisser", fordi han skulde have sagt, at han vilde rykke tyskheden i Tønder op med rode.

Han søgte ministeriet om ekstra bevillinger til afholdelse af fester på seminariet for at give det „en afgjort og udpræget na- 
tional dansk Characteer". Det lykkedes ham dog næppe ved disse fester at vinde hverken de nationalliberale embedsmænd eller de grundtvigske skolelærere, endsige borger og bonde.

Kongens fødselsdag i 1858 fejrede han ved i spidsen for alle seminaristerne med faner og syngende fædrelandssange at gå i optog gennem byen. På byens torv holdt han en tale for Frederik 7.: Grundloven, dagene ved Fredericia og Isted samt sprogreskriptet for Slesvig, det var Frederik 7.'s mindesmærker, „stolte som følgerige“. Bagefter samledes man til festmåltid i „Humlekærren". I et venligsindet referat $i$ "Vestslesvigsk Tidende" 19 hedder det: „En ægte dansk Gemytlighed herskede hele Aftenen igjennem og et fuldstændigt frit kammeratligt Forhold mellem Lærere og Elever gjorde et særdeles glædeligt Indtryk".

I februar 1859 benyttede den festglade Kühnel lejligheden til at fejre 200-årsdagen for stormen på København. Cornelius Appel, der var blevet knyttet som skrivelærer til seminariet, og som foreløbig stod $i$ et godt forhold til Kühnel, giver i „Vestslesvigsk Tidende $^{\text {"20 }}$ et velvilligt referat af festen. Der blev holdt et offentligt møde, hvor de fleste deltagere var byens borgere, der var mødt »i ret anseeligt Antal ", medens »den herboende forholdsvis talrige Embedsstand for en stor Deel holdt sig tilbage«. Der blev talt af kaptajn Thurah, seminariets dansk- og historielærer, og af Kühnel. Deres taler var, efter referatet at dømme, velegnede til - som Thurah udtrykte det - „at sætte Deeltagerne i den rette Stemning, hidse det danske Blod og bringe Følelsen i Varme ${ }^{u}$. Om aftenen samledes alle lærerne, en stor del af eleverne, „nogle af Borgerne og et Par af de i Byen boende Embedsmænd" til festmåltid i „Humlekærren".

Kongefesten i 1859 er ikke refereret af Appel. Derimod får den en såre ilde medfart $i$ bladet "Dannevirke“. Redaktionen af dette blad var i 1856 gået over fra P. Chr. Koch til Godske Nielsen, „en københavnsk Journalist, uden Forbindelse med Landsdelen og dens Befolkning“ (Nic. Svendsen).

Bladet begynder med at fortælle, at det synes, at de dansksindede har været for talrige til at rummes $i$ eet lokale til ballet på rådhuset, som magistraten havde indbudt til, „idet Seminariet denne Gang ligesom if jor havde en særlig Sammenkomst paa et Værtshuus, kaldet „Humlekærren“. Mulig kan Frygten for ikke at 
spille en tilstrækkelig fremtrædende Rolle ogsaa have bidraget Sit til Sondringen; men isaafald maa man glæde sig over det Fremop paa Torvet med hele Bataillonen og der gjorde Taler og lignende Gadeuorden".

Få dage efter denne salve berigtiger bladet sin fremstilling ved at fortælle: „Klokken 5 om Eftermiddagen saaes hele Bataillonen i sluttede Geledder med vaiende Faner og med Professoren i Spidsen at drage fra Seminariet op igjennem Østergade til Torvet, hvor da Bataillonen med et uhyre Tros af Ammer og Pattebørn gjorde Holdt og sluttede Kreds om Professoren, hvorpaa denne i sort Kjole og med hvide Handsker paa holdt en Tale, der skal have opbygget baade den ene og den anden Part af Tilhørerne. Efter Talen og Afsyngelsen af nogle Sange satte Bataillonen sig atter i Marsch igjennem Vestergade og tilbage igjen til „Humlekærren“. - Det glæder mig at kunne tilføje, at alle Embedsmændene havde den rigtige Takt at holde sig borte fra slige Demonstrationer, som mildest talt ere latterlige".

På disse ondskabsfuldheder svarede Kühnel, at flere af lærerne senere på aftenen havde deltaget $\mathrm{i}$ festen på rådhuset, og den besindige borgmester Holm kom med den erklæring, at det selvfølgelig ikke kunde falde ham ind "at henfore en offentlig Udtalelse af loyale Stemninger under Begrebet "Gadeuorden“"“ samt at det var begrundet $i$,en aldeles tilfældig Omstændighed“, at han ikke var tilstede ved den omhandlede lejlighed.

Men bladet fortsatte sit angreb: det måtte formodentlig ligge uden for formålet for det danske seminarium i Tønder at bidrage til "yderligere at skille de allerede iforveien saa splittede danske Kræfter der i Byen, hvilket skeer, naar Seminariet vil føle sig som en Stat i Staten". Endvidere: det går dog ikke an at ville "gjøre enhversomhelst Taktløshed skudfri ved at dække den med Loyalitetens og Danskhedens Banner"..21

Angrebene på Kühnel virker usmagelige. Men tilbage bliver den kendsgerning, at Kühnel ikke blev samlingsmærke for de danske kredse.

Embedsstanden kom ikke til hans fester. Appel understreger det med en vis glæde over at give et hip til embedsstanden - en samtidig avispolemik ${ }^{22}$ viser, at tidens spænding mellem sdegne- 
kristne" og gejstlighed også har sin plads i hans livshistorie. "Dannevirke" understreger embedsstandens udebliven med usminket skadefryd overfor Kühnel. Begge referater er således ensidigt farvede, men enige i kendsgerningen: embedsmændene holdt sig borte. Det skulde da heller ikke gøre Kühnels position bedre, at han i et forslag til en nyordning af skolevæsenet $i$ Tønder foreslog oprettet en højere borgerskole som øvelsesskole til seminariet under hans opsyn. Dermed vilde den vigtigste del af byens skolevæsen blive unddraget alt ovrigt tilsyn fra de lokale instanser, lige op til amtmand og provst.

Til kredsen omkring Appel kom Kühnel i et kedeligt misforhold. Appel gjorde sig ingen skrupler ved at samle en del af Kühnels elever om sig i fælles kritik af Kühnels religionsundervisning, fordi Kühnel, som det hed - med tro afspejling af Grundtvigs angreb på $H$. N. Clausen i "Kirkens Gjenmæle" -, forsømte at vise sine elever, at livet ikke skal søges „ved at læse Bibelen og faa den forklaret", men at livet og lyset skal søges "ved den rette Livs- og Lys-Kilde, ved Daaben nemlig“.

Hvor mange af byens borgere, der har deltaget i Kühnels fester, lader sig ikke afgore, men formodentlig er han blevet klar over, at Tønders befolkning ikke lod sig vinde ved nationale taler på torvet. I hvert fald synes han fra nu af at have indskrænket sig til at fejre de nationale højtidsdage ved interne fester på seminariet eller ved skoleudflugter. Et hårdt udtryk for en senere tids dom findes hos den eneste af de danske lærere fra mellemkrigstiden, der holdt ud i Tønder efter $1^{864^{23}}$ : „Hvor jammerlig forekommer mig nu den Holden Taler ved Festlejligheder om den danske Kjæmpekraft og den tyske Fejghed og lign. Pralerier, hvori Folk som Thurah og Kühnel havde deres Styrke, og hvis Hulhed de viste ved at være de forste til at flygte, da Dannevirke var rømmet".

Mest isoleret blev efterhånden den kreds, der gik under navnet „Klosterbrødrene“ (efter det bekendte møde i Løgumkloster den 25. apr. 1861). Appel er nok den, der har formået at give det klareste udtryk for bevægelsens ideer ${ }^{24}$. Man vilde advare mod at indlemme Slesvig i kongeriget, før der forelå en enig udtalelse fra slesvigerne selv. Man vilde lempe sprogreskripterne ved at åbne mulighed for tysk privatundervisning og for brug af tysk 
sprog ved den kirkelige del af konfirmationshandlingen. I øvrigt ønskede man aldeles ikke at omstøde den bestâende sprogordning og fandt aldeles ikke, at regeringen var trådt det tyske sprog for nær. Kun ønskede man, at der blev talt om sprogsagen „i en anden Tone", fordi „Befolkningen i Almindelighed trænger mere til at tales til rette end uden videre at sættes $i$ Ban".

For disse ideer gik man ind ved en række møder i landsdelen. I Tønder søgte man ved nogle møder i „Humlekærren“ (Hans Hage havde selv varet medindbyder til Klostermødet) at komme i kontakt med borgere, der — som Kjaer skrev — „ikke henregnes til de velsindede“. Kjaer, der pa det tidspunkt var konstitueret politimester i Tønder, var harmfnysende over disse moder, som blev loranstaltet af "Appel og disse to skrækkelige Størrelser Beck ${ }^{25}$ og Ley“. Han søgte at fả møderne forbudt og kaldte flere af deltagerne til forhør, hvor han — i hvert fald overfor Appel $^{26}$ - optrådte pá lidet værdig måde. Disse møder forte dog ikke til noget. Tidemands efterfølger, provst Hjort, fortæller $i$ et brev til Regenburg den 11. juli $1861:^{27}$ "Møderne paa Humlekærren mellem Lei og Appel og deres Venner osv. og Tydskerne ere nu revne ud, da de sidste uforbeholdent fordrede et S-H [Slesvig-Holsten] og stillede den "unzertrennliche Verbindung " op som conditio sine qua non".

Klosterfolkene var kommet i vanry. Det skyldtes deres forsøg på at komme på talefod med de nationale modstandere. Det skyldtes, at man — måske særlig takket være Leys tågede sprog - troede, at de onskede sprogreskripterne ophævet. Mange betragtede dem som „halve Tyskere“. -

De danske kredse i Tonder slod splittede i deme periode. "Den gode sag " formâede ikke at samle dem i falles mode- og forenings" liv. Personlige kompetencestridigheder har spillet ind. Men mere vaesentlig var nok den forskellige målsæatning.

En yderliggående gruppe representeredes først og fremmest af Kjar, der satte det som sit mål at „fremtvinge Sandheden i denne fatale By", eller af Kühnel, der vilde rykke tyskheden op med rode. Gennem daniseringen vilde man $i$ disse kredse vinde Slesvig for Danmark og således undergrave den forhadte helstatspolitik. Man vilde, som det blev sagt, følge „en ophøjet politisk Teoris Bud“. 
Klosterfolkenes mâl var at gengive den slesvigske befolkning dens danske modersmal udira den tankegang, at det andelige liv uddor hos en befolkning, der mister sit modersmal. Af menneskelige og kristelige, mere end af politiske grunde anså de det derfor nodvendigt at standse, hvad Chr. Flor kaldte fortyskningens "græsselige Mordervandring“ mod nord.

„Den grevelige Fraktion“ endelig - grev Reventlow og hans meningsfaller - vilde loyalt følge den helstatslinie, som regeringen havde forpligtet sig til efter trearskrigen, og formanede til god forstaelse mellem danske og tyske.

Resultatel blev, at når grev Reventlow søgte at administrere sprogreskripterne udfa den mildest mulige fortolkning, blev han af de yderliggående indrangeret blandt de "falske“ forsoningsfolk. Nar det truede med, at klosterfolkene med deres grundlvigske frihedsideer skulde bringe forvirring ind i sprogpolitikken, mátte greven tage affære overfor dem. Og endelig var det komplet umuligt for folk som Kjær og Appel at råbe hinanden op. Lad sâ være, at billedet her er stillet vel skematisk op, og at standpunkterne hos de enkelte er mere nuanceret. Så meget mere kaotisk bliver billedet.

Der er noget vist tragisk i det hele. I idealistisk nidkærhed for "den gode sag" sled haderlige og velmenende danske mænd sig op i indbyrdes rivninger, medens samtidig en kyndig slesviger som biskop Martensen vurderede den danske sprogpolitik som forfejlet. Han nægtede at pátage sig embedet som biskop over Slesvig stift og dermed medansvaret for den danske sprogpolitik. Medens sprogreskriptets folk lod sig lede af politiske eller religiøse teorier, sâ han ganske noglernt på kendsgerningerne, der for ham tegnede sig säledes: Befolkningen i Mellemslesvig havde i ârhuıdreder, trods sit danske talesprog, haft tysk kirke- og skolesprog. Dens dinske sprog var derfor blevet berovet andelighedens karakter og indeholdt kun hverdagsudtryk, ord for det daglige livs foreteelser. De andelige forestillinger var menighederne vant til at udtrykke $i$ ord fra Luthers tyske bibeloversættelse, fra den tyske salmebog og fra den tyske katekisme. Derfor kunde man ikke gennemføre fordanskningen i kirke og skole uden at skade det andelige liv.

De talrige adresser og petitioner, hvori befolkningens modstand 
mod sprogreskriplerne kom til udtryk, rummer bag deres voldsomme sprog tanker, der harmonerer med Martensens. I disse adresser betones det sảledes, at man havde modtaget „wie den Glauben so die Sprache“. IIvis man fjernede det tyske sprog fra kirken, vilde folket holde sig borte fra gudstjenesten og dermed blive berovet tro og sadelighed. Og videre hed det: Nár børnene larte at udtrykke deres religiøse følelser pâ dansk, og forældrene kun kunde udtrykke dem pá tysk, sâ vilde forældrenes indflydelse pâ bornenes sind blive svakket.

De nationale lidenskaber hos modstanderne af sprogreskriplerne gav ofte protesladresserne en voldsom agitatorisk karakter. () g de samme lidenskaber medforte til gengald, al man fra dansk side kun betraglede protesterne som danskfjendtlig agitation.

For at vurdere sagen retfardigt vil det vare formástjenligt at se et sprogskiftes problemer belyst udfra en situation, hvor sprogskiftet ikke har sin baggrund i en national kamp, og hvor billedet derfor ikke sløres af følelsesbestemte indslag.

Om sprogskiftets problemer blandt emigranter i U.S.A. hedder det hos en kyndig iagttager (den dansk-norske forfatter $O$. E. Rolvalag) ${ }^{28}$, at det nærmest er umuligt for et menneske af gennemsnittet at opgive et sprog og tilegne sig et nyt sprog. „Han kan ikke opgive det gamle, det vilde betyde deden for ham, og han kan ikke mestre det nye - processen overstiger simpelthen hans evner... At tilegne sig et sprog betyder ikke netop at samle de ord og udtryk op, som bruges i handels- og rejselivet - det kan de fleste gore. Jeg tenker på at beherske et fremmed sprog sâ intimt, at ens følelsesliv kan bevege sig frit og naturligt i det nye medium. Ikke for dette mirakel har fundet sted, kan man fole sig helt hjemme i et nyt land. Jeg kalder det et mirakel, for så vil ens sjal vare blevet forvandlet". Videre understreges det, hvor tragisk del er, når harnet fár et andet sprog end moderen. „Hendes sange kan det ikke forstâ, hvad hendes sjal har fundet næring $i$, kan det ikke begribe... Der er tragedier i livet, for hvilke sproget ikke har noget nojagtigt udtryk - dette er en af dem".

Selvf(slgelig er der forskel på situationen blandt emigranter i U.S.A. og grænsebefolkningen i Sønderjylland. Men det her anforte gor det dog klart, at Martensen havde ret $i$, at et sprogskifte 
netop indenfor religionsundervisningen og den kirkelige forkyndelse ikke uden videre lader sig gennemføre efter sprogreskripternes recept, og gør det endvidere klart, at man ikke summarisk kan affeje protestadresserne mod sprogreskripterne som ren og skær antidansk agitation. Det er en mere kompliceret affære at løse et grænselands sprogproblem, end datiden - iøvrigt ogsâ andre steder end i Danmark - gjorde sig klart. Dette rummer måske noget af forklaringen på forvirringen blandt forkæmperne for „den gode Sag“ i Tønder.

\section{NOTER OG HENVISNINGER}

1. Schl.-Holst. Provinzialberichte 1822, IV, s. 84.

2. Tønder Seminariums arkiv. Sager $1788-1855$, pag. 182. LA Ảb.

3. Sst. pag. 193.

4. Schl.-Holst. Provinzialberichte 1817, s. 113.

5. SJy Årb. 1890, s. $124 \mathrm{ff}$.

6. Corn. Appel i Hejmdal 28/3 1901.

7. Kjær t. Regenburg 12/5 1851, Regenb. Ark. RArk.

8. Kjær t. Regenb. $22 / 4$ 1853, Regenb. Ark. RArk.

9. K jær t. Regenb. 13/9 1857, Regenb. Ark RArk.

10. Dannevirke $8 / 111852$.

11. Dannevirke 21/1 1856 .

12. W. Christiansen i Sprogforeningens Almanak 1956, s. 52 f.

13. SJy Årb. 1890, s. 173 .

14. Budstikken 15/11 1855, nr. 22, s. 694 .

15. Dannevirke 10/10 1856 .

16. Dansk Kirketidende 2/11 1851 , nr. 44 og $22 / 21852$, nr. $\mathrm{K}$.

17. Tidemand t. Regenb. 19/3 1856, Regenb. Ark. RArk.

18. Tidemand t. Regenl. 19/4 1856, Regenb. Ark. RArk.

19. Vestslesv. Tidende 9/10 1858.

20. Vestslesv. 'Tidende $14 / 21859$.

21. Dannevirke 11/10,15/10,18/10, 20/10 1859. Vestslesv. Tidende $19 / 10,21 / 10,26 / 101859$.

22. Dannevirke $20 / 91859$.

23. Vilh. Hagerup, SJy Årb. 1942, s. 239.

24. Vestslesv. Tidende $22 / 5$ og $27 / 51861$.

25. Beck var gârdejer i Visby. Ley var en tid huskerer hos ham.

26. SJy Årb. 1956, s. 190 ff.

27. Hjort t. Regenb. Regenb. Ark. RArk.

28. Paul C. Nyholm: The Americanization of the Danish I.utheran Churches in America. Udg. af Instituttet for dansk kirkehistorie, 1963 , s. $46 \mathrm{f}$. 